\title{
Changing Land Use Patterns and Their Impacts on Wild Ungulates in Kimana Wetland Ecosystem, Kenya
}

\author{
Stephen Kitina Nyamasyo ${ }^{1}$ and Bonface Odiara Kihima ${ }^{2}$ \\ ${ }^{1}$ Wildlife Management, Kenya Wildlife Service Training Institute, P.O. Box 842, Naivasha 20117, Kenya \\ ${ }^{2}$ Hospitality and Tourism, Kenyatta University, P.O. Box 16778, Mombasa 80100, Kenya \\ Correspondence should be addressed to Bonface Odiara Kihima; odiarab@yahoo.fr
}

Received 26 May 2014; Revised 15 October 2014; Accepted 29 October 2014; Published 3 December 2014

Academic Editor: Arianna Azzellino

Copyright (c) 2014 S. Kitina Nyamasyo and B. Odiara Kihima. This is an open access article distributed under the Creative Commons Attribution License, which permits unrestricted use, distribution, and reproduction in any medium, provided the original work is properly cited.

\begin{abstract}
In Kenya, wildlife numbers have drastically declined due to land use changes (LUCs) over the past three decades. This has affected wildlife habitats by converting them into farmlands and human settlements. This study used remote sensing data from landsat satellite to analyze the changing land use patterns between 1980 and 2013 and their impacts on wild ungulates in KWE. The objective of the study was to map out LUCs, determine the possible causes of LUCs, and examine the effects of LUCs on wild ungulates. The results showed a noticeable increase in the size of farmland, settlement, and other lands and a decline in forestland, grassland, wetland, and woodland. The main possible causes of LUC were found to be agricultural expansions, human population dynamics, economic factors, changing land tenure policy, politics, and sociocultural factors. The main effects of LUCs on wild ungulates in KWE include a decline in wild ungulate numbers, habitat destruction, increased human-wildlife conflicts, land degradation, and displacement of wild ungulates by livestock. The study recommends land use zoning of KWE and establishment of an effective and efficient wildlife benefit-sharing scheme(s).
\end{abstract}

\section{Introduction}

Wild ungulates are hoofed wild mammals comprising large grazers and browsers. They account for the vast majority of large herbivores currently on earth and are found in nearly every biome especially in arid and semiarid grasslands [1]. Their abundance and spatial distribution is highly related to availability of quality forage and water resources [2].

Wild ungulates have high economic values as a source of revenue through consumptive and nonconsumptive utilization $[3,4]$. Their resources provide environmental goods and services for the livelihood of the people, sociocultural, aesthetic, and ecological values. In Kenya, wildlife resources accounted for $70 \%$ of the gross tourism earnings, $25 \%$ of the gross domestic product (GDP), and more than $10 \%$ of total formal sector employment in 2011 [5].

Although Africa has been exceptional in retaining a considerable diversity and concentration of its wildlife compared to America and Australia, the populations of many of its wild ungulate species have declined substantially inside and outside protected areas over the past three decades $[6,7]$. East Africa was incomparable in sustaining relatively intact wildlife but in the last three decades the wild ungulate population has declined sharply [8].

Kenya is ranked second highest among African countries, in bird and mammal species richness with an estimate of 394 mammals, 1100 birds, 201 reptiles (100 lizards, 100 snakes, and 1 crocodile), 100 amphibians, and 950 (250 freshwater and 700 marine) fish species. However, over the last 30 years, her wildlife numbers have shrunk by between $35 \%$ and $50 \%$ [9] and, by 2006, the number of threatened species in Kenya included 33 species of mammals [10]. This decline in wildlife numbers globally, regionally, and locally has more been attributed to land use changes, human encroachment into wildlife habitats, recurrent droughts, poaching, and other anthropogenic activities [11, 12].

Land use changes affect key aspects of the earth's functioning, including a direct impact on global biodiversity [13, 
14]. In East Africa, land use changes have transformed land cover to farmlands, livestock grazing lands, mining grounds, human settlements, and urban centers at the expense of wildlife habitat [15]. These changes are associated with wildlife losses, habitat destruction, land degradation, and blockage of wildlife corridors $[15,16]$.

In Kenya, increase in human population is rapidly leading to encroachment into wildlife habitats [17] leading to the reduction of wildlife space and blockage of wildlife corridors. If protected areas have no wildlife corridors, genetic drift and inbreeding may occur, thus leading to population instability, loss of ecological integrity, and possibly local extinction and increase in human-wildlife conflict $[18,19]$. Such conflicts create frustration and animosity towards wildlife and may result in retaliatory killings $[20,21]$. The threat to wild ungulate populations is, therefore, an eminent one for Kenya, particularly when one considers the fact that many of her protected areas are increasingly becoming insularized as a result of the expanding human dominated areas $[21,22]$.

Despite the massive conservation efforts backed by significant international support, changes in land use patterns and associated impacts of human activities continue to accelerate the rate of wildlife habitat conversion in KWE. The impacts of land use changes on wild ungulates in KWE have not yet been fully appreciated. Information on their manifestation and intensity is inadequate despite its importance in formulating mitigation measures. This has made it difficult to mitigate wetlands, wildlife habitats, and wild ungulate losses as well as their conservation in KWE. The study sought to determine the changing land use patterns in KWE from 1980 to 2013 and thereafter determine the possible causes of land use changes and effects of land use on wild ungulate population. The study hypothesized that changes in land use pattern have led to a significant decline on the population of wild ungulates in KWE and that the increase in human population and associated activities are the possible causes of land use changes in KWE formulated as follows.

(a) $\mathrm{H}_{\mathrm{O}}$ : there has been no significant increase on land use changes in KWE from 1980 to 2013.

(b) $\mathrm{H}_{\mathrm{O}}$ : changes in land use patterns in KWE have not had significant effects on the wild ungulate populations.

(c) $\mathrm{H}_{\mathrm{O}}$ : increase in livestock population and tourism activities in KWE have not resulted into a noticeable decline in wild ungulate numbers in KWE.

\section{Study Area}

Kimana wetland ecosystem (KWE) measures 3,348 $\mathrm{Km}^{2}$ and is located in Kajiado County. It lies between longitudes $36^{\circ} 5^{\prime}$ and $37^{\circ} 5^{\prime}$ east and latitudes $1^{\circ} 0^{\prime}$ and $3^{\circ} 0^{\prime}$ south. KWE comprises Kimana division $\left(358.8 \mathrm{~km}^{2}\right)$, Entonet division $\left(1,349.3 \mathrm{~km}^{2}\right)$, Central division $\left(1,280.3 \mathrm{~km}^{2}\right)$, Imbirikani Location $\left(339.8 \mathrm{~km}^{2}\right)$, and Amboseli National Park (ANP) $\left(392 \mathrm{~km}^{2}\right)$. It is a wildlife rich area consisting of ANP and nine group ranches each with a conservancy or a wildlife sanctuary. It borders Chyulu and Tsavo West National Parks to the east and is a critical wildlife dispersal area for the larger Tsavo-Amboseli ecosystem.

The area has a number of permanent swamps such as Amboseli, Kimana, and NOLTRUSH swamps which provide suitable ground for agriculture while the entire range is suitable for wildlife and pastoralism [23]. Dominant vegetation includes grasses, shrubs, and Acacia plant species that are adapted to long drought periods. The mega ungulates found in the ecosystem include African elephant (Loxodonta africana), African buffalo (Syncerus caffer caffer), common eland (Tragelaphus oryx), and Maasai giraffe (Giraffa camelopardalis tippelskirchi). The mini ungulates found in the area include plains zebra (Equus burchelli), common duiker (Sylvicapra grimmia), impala (Aepyceros melampus), Thomson's gazelle (Gazella thomsonii), Grant's gazelle (Gazella granti), common waterbuck (Kobus ellipsiprymnus), and Kirk's dik-dik (Madoqua kirkii). The big cats include lion (Panthera leo), spotted hyena (Crocuta crocuta), leopard (Panthera pardus), and cheetah (Acinonyx jubatus). The ecosystem also supports a large population of small mammals, reptiles, and amphibians. The wetland has a rich birdlife, with over 400 species recorded, of which 40 are birds of prey [23]. It has globally threatened bird species such as Lesser kestrel, restricted-range birds found only in a small area such as the Taveta golden weaver, bird species that live only in a particular vegetation type such as the grosbeak weaver, and regionally threatened bird species such as martial eagles.

KWE is primarily habited by Maasai who are seminomadic pastoralists with land being communally owned. Their lifestyle has, however, undergone changes due to ongoing land adjudication and subdivision of group ranches leading to private land tenure system. This has increased the rate of land sales and created openings to emigrations especially in the relatively high agricultural potential areas such as Kimana, Entonet, and Kuku divisions. Emigrating communities are farmers from other parts of the country.

\section{Methodology}

Primary data collected included TM Landsat satellite (acquired from path/row 168/062 and 167/062) images of 1980, 1990, 2000, 2010, and 2013. Current land use types, notable land use changes over time, land tenure system, and socioeconomic data from 200 households and 20 institutions were collected using semistructured questionnaires and interview schedules, respectively.

To arrive at the sample, the population was divided into clusters including Amboseli, Olchoro, Imbirikani, Kimana, Inkariak Ronkena, Kuku, Loolopon, and Entonet after which individuals were randomly selected depending on the size of the area and human population density as follows: Kimana and Kuku division, 30 households each; Olchoro, Loolopon, Entonet, and Inkariak Ronkena, 25 households each; and Amboseli and Imbirikani, 20 households each. Interviews were conducted randomly using semistructured questions. Only an adult family head (man or woman) was interviewed per household but he or she was free to seek help from any other family member in case of difficulties in responding to 
questions. For institutions, only the longest serving officer who was perceived to be more knowledgeable on the study area was interviewed and he/she was free to seek help from any other officer in case of difficulties.

Secondary data collected included KWE topographical map, land use types, causes of land use changes and its effects on wild ungulates, human population census figures, wild ungulate population census data, and livestock population trend. Land use change data was gathered through acquisition, interpretation, and analyses of satellite images using ARCGIS and EDRAS software. Human, livestock, and wild ungulates numbers were obtained from Loitokitok district development plan, KNBS, ILRI, DRSRS, and KWS.

Direct observation was also employed on identification of wild ungulate species, current land use types, land degradation, and wetland encroachment. This encompassed a line transect walk running diagonally from Kimana sublocation to Isenet through Kimana community wildlife sanctuary covering a distance of $60 \mathrm{~km}$. It was carried out with the help of community game scouts patrolling at the edges of the wildlife corridors where irrigated farms are concentrated. All the wild ungulates species found at a distance of $1 \mathrm{Km}$ on both sides of the line transect walk were identified and individual species counted. This took place during the month of April (onset of the long rains) 2013 and lasted three days. During the month of April wild ungulates are mostly concentrated in swampy places because of availability of water and pasture. Photographs were employed to capture data using a digital camera. It helped in the classification of land uses in the areas as an evidence of actual practices taking place.

To enhance the change detection, field visits were conducted to make ground truthing. This involved selecting of sites at random from the latest land use base map and visiting of each site to check and verify whether the land use type on the actual ground was what was shown on the map. Five sets of images representing a temporal period of 33 years from 1980 to 2013 were acquired.

The TM Landsat satellite image of 1980 was georeferenced against a topographic map at a scale of 1/50,000 using a number of ground control points, which were obtained after visiting the study area. The projection was Universal Transverse Mercator (UTM) with Arc 1960 as datum. Image to image registration was then performed by georeferencing satellite images of 1990, 2000, 2010, and 2013 from TM Landsat against the georeferenced TM Landsat satellite images of 1980. This ensured that the pixel grids of 1990, 2000, 2010, and 2013 images conform to georeferenced image of 1980, to enable pixel-by-pixel comparison of the images. The images were then analyzed to determine various land use types. Changes in land use classes were mapped and quantified and accuracy assessment was done for all.

\section{Data Analysis}

The satellite images were analyzed and interpreted using GIS Arc Map and ERDAS Images software. Data on socioeconomic, wild ungulate, and livestock statistics was analyzed using SPSS software version 17 and Microsoft excel. Land use changes data was analyzed using descriptive statistics to show the variation from 1980 to 2013. This involved calculation of size of areas under each land use for the years 1980, 1990, 2000, 2010, and 2013 and their sizes computed. This capability is provided in area command under the database query module in Arc Map. The areas were then entered in Microsoft excel for the computation of land use changes over time. To determine the land use change for a particular land use, the area of land for year 1980 was subtracted from the area of land for the year 2013. Pearson correlation coefficient statistics analysis was performed to determine association between changes in different land uses in Kimana wetland ecosystem. Frequencies of interviewed household heads and institutions giving a particular response were summarized. The equalities of frequencies were tested using chi-square goodness of fit. To establish possible causes of land use changes the frequencies of the responses of those interviewed were summarized and a chi-square cross tabulations analysis was performed to determine the relationship with specific attributes. Statistical tests were considered significant if $P$ values were equal to or less than 0.05 and insignificant if $P$ values were greater than 0.05 [24]. For chi-square cross tabulations, if $P$ value was equal to or less than 0.05 , then a response was dependent on an attribute and independent of the attribute if $P$ value was greater than 0.05 .

\section{Findings}

5.1. Major Land Use Changes in Kimana Wetland Ecosystem $(K W E)$. This research produced seven important land use types including farm/cropland, settlement and urban areas, forestland, grassland, woodland, wetland/swamps, and other lands (bare and rocky grounds, built areas, quarries, roads, dried up wetland/swamps, and abandoned human settlement) (Figure 1). In 1980, Kimana wetland ecosystem had a total area of $3,348.66 \mathrm{~km}^{2}$ (Table 1 ) out of which farm/cropland had occupied $69.97 \mathrm{~km}^{2}$; settlement and urban areas, $2.08 \mathrm{~km}^{2}$; forestland, $62.27 \mathrm{~km}^{2}$; grassland, $2,555.71 \mathrm{~km}^{2}$; woodland, $58.93 \mathrm{~km}^{2}$; wetland/swamps, $492.66 \mathrm{~km}^{2}$; and other lands, $108.4 \mathrm{~km}^{2}$. By 2013 farm/cropland occupied an area of $438.17 \mathrm{~km}^{2}$; settlement and urban areas, $16.26 \mathrm{~km}^{2}$; other lands, $303.47 \mathrm{~km}^{2}$; forestland, $32.65 \mathrm{~km}^{2}$; grassland, $2,349.13 \mathrm{~km}^{2}$; wetland, $153.05 \mathrm{~km}^{2}$; and woodland, $55.78 \mathrm{~km}^{2}$ (Figure 2).

A significant positive correlation occurred between cropland and settlement areas $(r=0.989, \mathrm{DF}=2, P=0.001)$ and farm/cropland and other lands $(r=0.952, \mathrm{DF}=2, P=$ 0.013). On the other hand, a significant negative correlation occurred between cropland and forestland $(r=-0.989, \mathrm{DF}=$ $2, P=0.001)$, cropland and grassland $(r=-0.989, \mathrm{DF}=2$, $P=0.001)$, cropland and wetland $(r=-0.997, \mathrm{DF}=2$, $P=0.004)$, and cropland and woodland $(r=-0.922, \mathrm{DF}=$ $2, P=0.026)$. Another negative correlation also occurred between settlement and forestland $(r=-0.986, \mathrm{DF}=2$, $P=0.002)$, settlement and grassland $(r=-0.980, \mathrm{DF}=2$, $P=0.004)$, and other lands and wetland $(r=-0.985, \mathrm{DF}=2$, $P=0.015)$ (Table 2). 
TABLE 1: The area $\left(\mathrm{km}^{2}\right)$ and the percent land cover for land use changes in KWE.

\begin{tabular}{lccccccccccc}
\hline $\begin{array}{l}\text { Land use } \\
\text { types }\end{array}$ & $\begin{array}{c}1980 \\
\left(\mathrm{~km}^{2}\right)\end{array}$ & $\begin{array}{c}\mathrm{RLC} \\
(\%)\end{array}$ & $\begin{array}{c}1990 \\
\left(\mathrm{~km}^{2}\right)\end{array}$ & $\begin{array}{c}\mathrm{RLC} \\
(\%)\end{array}$ & $\begin{array}{c}2000 \\
\left(\mathrm{~km}^{2}\right)\end{array}$ & $\begin{array}{c}\mathrm{RLC} \\
(\%)\end{array}$ & $\begin{array}{c}2010 \\
\left(\mathrm{~km}^{2}\right)\end{array}$ & $\begin{array}{c}\text { RLC } \\
(\%)\end{array}$ & $\begin{array}{c}2013 \\
\left(\mathrm{~km}^{2}\right)\end{array}$ & $\begin{array}{c}\text { RLC } \\
(\%)\end{array}$ & $\begin{array}{c}\% \text { increase } \\
(+) \text { or } \\
\mathrm{dec}\end{array}$ \\
\hline Settlement & 2.08 & 0.00 & 4.16 & $0.12 \%$ & 7.78 & $0.23 \%$ & 15.10 & $0.45 \%$ & 16.26 & 0.49 & $681.57 \%$ \\
Woodland & 58.93 & $1.76 \%$ & 58.93 & $1.76 \%$ & 56.54 & $1.69 \%$ & 56.24 & $1.68 \%$ & 55.78 & 1.67 & $-5.35 \%$ \\
Cropland & 69.97 & $2.09 \%$ & 176.06 & $5.26 \%$ & 263.63 & $7.87 \%$ & 421.23 & $12.58 \%$ & 438.17 & 13.09 & $526.21 \%$ \\
Forestland & 62.27 & $1.86 \%$ & 57.6 & $1.72 \%$ & 45.12 & $1.35 \%$ & 34.53 & $1.03 \%$ & 32.65 & 0.98 & $-47.56 \%$ \\
Other lands & 108.04 & $3.23 \%$ & 202.61 & $6.05 \%$ & 246.3 & $7.36 \%$ & 271.78 & $8.12 \%$ & 303.47 & 9.06 & $180.89 \%$ \\
Wetland & 492.66 & $14.71 \%$ & 368.92 & $11.02 \%$ & 262.72 & $7.85 \%$ & 197.63 & $5.90 \%$ & 153.05 & 4.57 & $-68.93 \%$ \\
Grassland & 2555.71 & $76.32 \%$ & 2480.37 & $74.07 \%$ & 2466.56 & $73.66 \%$ & 2351.95 & $70.24 \%$ & 2349.132 & 70.15 & $-8.08 \%$ \\
\hline Total & 3348.66 & $100.00 \%$ & 3348.65 & $100.00 \%$ & 3348.65 & $100.00 \%$ & 3348.46 & $100.00 \%$ & 3348.51 & 100.00 & \\
\hline
\end{tabular}
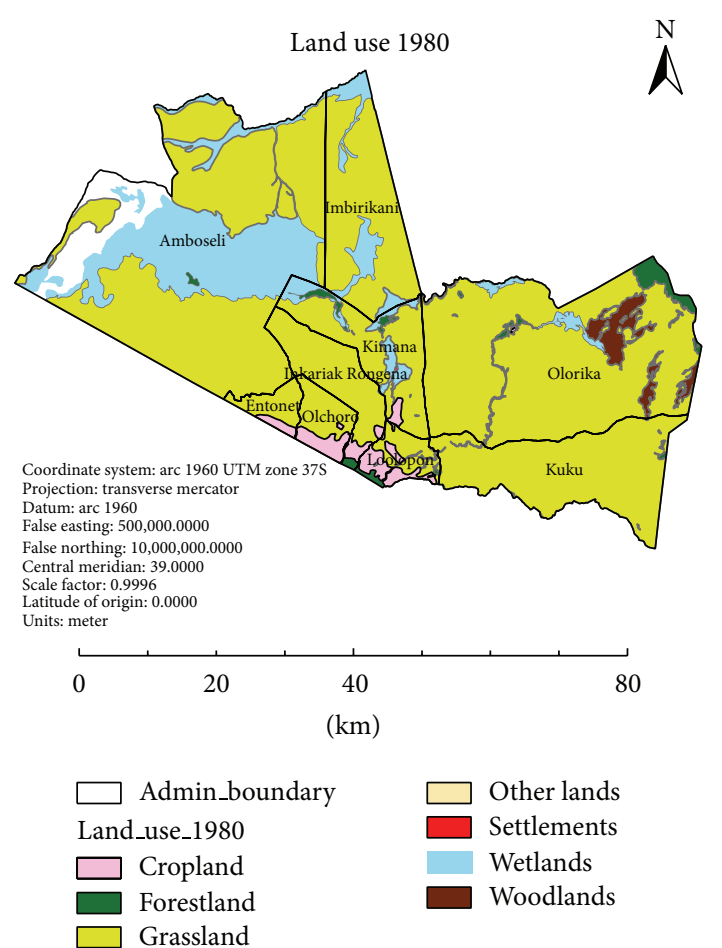

Figure 1: Land use map of 1980 for Kimana wetland ecosystem. Source: author, 2013.

Farm/cropland, settlement and urban areas, and other lands in KWE are becoming important with time as they replace the areas previously occupied by wetland/swamps, grassland (wildlife dispersal, corridors, and breeding areas), forestland, and woodlands. It was also established from the study that none of the areas that had initially been wetlands and then converted to cropland ever reverted to wetland. Field observations revealed that wetlands play a key role in irrigated farming whereby all the water used for irrigation is pumped directly from the wetlands.

5.2. Causes of Land Use Change in Kimana Wetland Ecosystem $(K W E)$. The main causes of land use change in KWE as indicated by the respondents include agricultural expansions

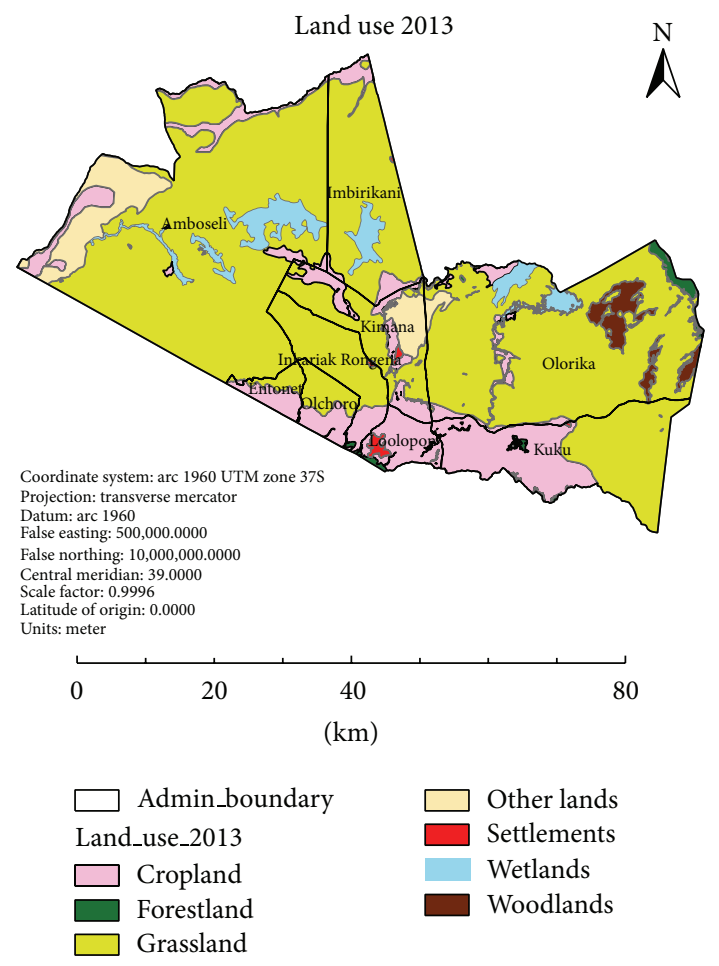

FIGURE 2: Land use map of 2013 for KWE. Source: author, 2013.

(31.5\%), human population dynamics (25.5\%), economic factors (high financial gains from cultivation compared to pastoralism and wildlife-based tourism) (13\%), changing land tenure policy (10.5\%), politics (10.5\%), drought, and sociocultural factors such as poverty, level of education, urbanization, and culture change (Table 3 ). Only opinions from those respondents who had lived in the area for more than five years were considered. Such was dependent on the current land uses and length of stay $\left(\chi^{2}=47.64, \mathrm{DF}=28\right.$, $\left.P=0.012 ; \chi^{2}=46.52, \mathrm{DF}=28, P=0.024\right)$ but independent on age, level of education, land tenure system, and sources of livelihood (Table 5). Farmers and business people attributed the causes of land use change in the area to agricultural expansions and economic gains while pastoralist attributed it to drought and sociocultural factors. 
TABLE 2: Correlations between land use changes in KWE.

\begin{tabular}{|c|c|c|c|c|c|c|c|c|}
\hline Land use type & Correlation & Cropland & Wetland & Settlement & Other lands & Forestland & Grassland & Woodland \\
\hline \multirow{2}{*}{ Crop } & Pearson correlation & 1 & $-0.979^{* *}$ & $0.989^{* *}$ & $0.952^{*}$ & $-0.989^{* *}$ & $-0.989^{* *}$ & $-0.922^{*}$ \\
\hline & sig. (2-tailed) & & 0.004 & 0.001 & 0.013 & 0.001 & 0.001 & 0.026 \\
\hline \multirow{2}{*}{ Wetland } & Pearson correlation & $-0.979^{* *}$ & 1 & $-0.946^{*}$ & $-0.990^{* *}$ & $0.974^{* *}$ & $0.951^{*}$ & $0.939^{*}$ \\
\hline & sig. (2-tailed) & 0.004 & & 0.015 & 0.001 & 0.005 & 0.013 & 0.018 \\
\hline \multirow{2}{*}{ Settlement } & Pearson correlation & $0.989^{* *}$ & $-0.946^{*}$ & 1 & $0.903^{*}$ & $-0.986^{* *}$ & $-0.980^{* *}$ & $-0.918^{*}$ \\
\hline & sig. (2-tailed) & 0.001 & 0.015 & & 0.036 & 0.002 & 0.004 & 0.028 \\
\hline \multirow{2}{*}{ Other lands } & Pearson correlation & $0.952^{*}$ & $-0.990^{* *}$ & $0.903^{*}$ & 1 & $-0.934^{*}$ & $-0.931^{*}$ & $-0.890^{*}$ \\
\hline & sig. (2-tailed) & 0.013 & 0.001 & 0.036 & & 0.020 & 0.022 & 0.043 \\
\hline \multirow{2}{*}{ Forestland } & Pearson correlation & $-0.989^{* *}$ & $0.974^{* *}$ & $-0.986^{* *}$ & $-0.934^{*}$ & 1 & $0.959^{* *}$ & $0.967^{* *}$ \\
\hline & sig. (2-tailed) & 0.001 & 0.005 & 0.002 & 0.020 & & 0.010 & 0.007 \\
\hline \multirow{2}{*}{ Grassland } & Pearson correlation & $-0.989^{* *}$ & $0.951^{*}$ & $-0.980^{* *}$ & $-0.931^{*}$ & $0.959^{* *}$ & 1 & 0.856 \\
\hline & sig. (2-tailed) & 0.001 & 0.013 & 0.004 & 0.022 & 0.010 & & 0.064 \\
\hline \multirow{2}{*}{ Woodland } & Pearson correlation & $-0.922^{*}$ & $0.939^{*}$ & $-0.918^{*}$ & $-0.890^{*}$ & $0.967^{* *}$ & 0.856 & 1 \\
\hline & sig. (2-tailed) & 0.026 & 0.018 & 0.028 & 0.043 & 0.007 & 0.064 & \\
\hline
\end{tabular}

${ }^{* *}$ Correlation is significant at the 0.01 level (2-tailed)

${ }^{*}$ Correlation is significant at the 0.05 level (2-tailed).

TABLE 3: Respondent's opinions on the causes for land use change in KWE.

\begin{tabular}{lcc}
\hline Possible causes of land use change & $\begin{array}{c}\text { Number of } \\
\text { respondents }\end{array}$ & Percentage \\
\hline Agricultural expansion & 63 & 31.5 \\
Human population increase & 51 & 25.5 \\
Economic forces & 26 & 13.0 \\
Politics & 21 & 10.5 \\
Changing land tenure policy & 21 & 10.5 \\
Drought & 8 & 4.0 \\
Poverty & 6 & 3.0 \\
Education level & 4 & 2.0 \\
\hline Total & 200 & 100.0 \\
\hline
\end{tabular}

Source: author, 2013.

5.3. Agricultural Expansion. Irrigated agricultural field in KWE increased from $69.97 \mathrm{~km}^{2}$ in 1980 to over $438.17 \mathrm{~km}^{2}$ in 2013 (Table 1) suggesting that irrigated agricultural expansion is one of the major causes of land use change (Table 3). This expansion has seen irrigated agriculture become the main source of livelihood for the households in KWE as indicated by $39 \%$ of the respondents. The main crops grown currently in the area are horticultural crops such as tomatoes, chilli, onion, and kales among others while maize and beans were the main food crops.

5.4. Demographic Dynamics. Over the past three decades, KWE has experienced an estimated annual human population growth rate of 4.67 as per the 2009 census. This translated into 84,297 persons and a population density of 25.2 persons $/ \mathrm{km}^{2}$ in 2009 with Kimana division having the highest at 57 persons $/ \mathrm{km}^{2}$. It is projected that by the year 2030 , the total human population in the area will be 210,789

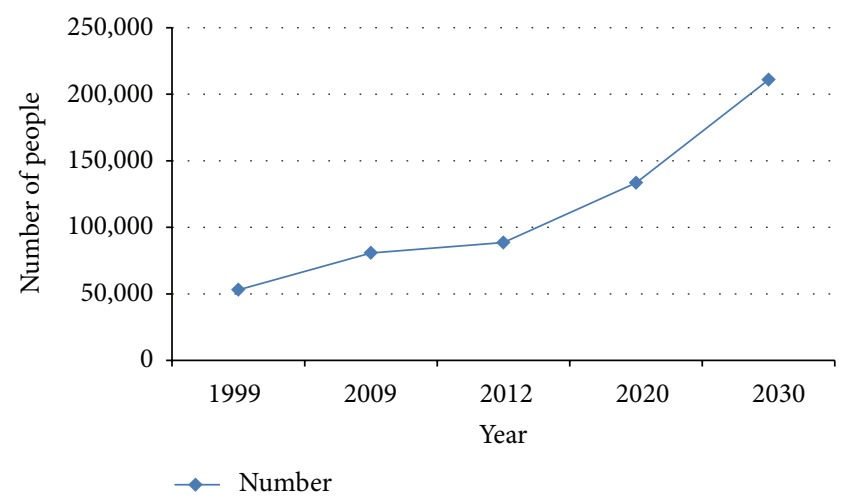

FIGURE 3: Projected human population for KWE up to the year 2030. Source: GoK [25].

(Figure 3). The rapid population growth in the area has resulted in increased demand for more land for farming, settlement, and infrastructure development which has led to clearing of large areas of the wetland, forestland, woodland, and grassland that serves as habitats for wild ungulates.

5.5. Economic Factors. Of the total number of respondents interviewed, $82 \%$ pointed out that they receive virtually no direct cash benefits from the wildlife-based tourism industry. They only receive indirect benefits in the form of school bursaries, piped water, construction of classrooms and dispensaries, livestock sales yards, and other related community goods and services, which often fail to benefit those in most need. In contrast, they indicated that they receive direct benefits from irrigated farming and selling or renting out their land.

Increased demand for agricultural produce to satisfy the local markets and border towns such as Moshi, Arusha, and Tarakea in Tanzania has accelerated the rate of irrigated 
TABLE 4: Size of land owned by individuals in KWE.

\begin{tabular}{lcc}
\hline Size of land & Frequency & Percent \\
\hline$<2.5$ Acres & 80 & 40 \\
$2.5-5$ Acres & 73 & 36.5 \\
$5.1-7.5$ Acres & 20 & 10 \\
$7.6-10$ Acres & 16 & 8 \\
Above 10.1 Acres & 11 & 5.5 \\
\hline Total & 200 & 100 \\
\hline
\end{tabular}

Source: author, 2013.

farming in the area as denoted by $86 \%$ of the respondents. The study found that approximately 20,000 tons of farm produce is harvested and transported to Tanzania, Nairobi, and Mombasa markets weekly.

Moreover, the introduction of irrigated small-scale farming in the area in the early 1970s after the collapse of group ranch model gave rise to increased demand for more land for irrigated farming as revealed by $82 \%$ of the respondents. The government welcomed subdivision and in 1981 enacted a policy to promote it. This increased demand for more land for irrigated farming resulted in further land subdivision. The study found that $65 \%$ of those interviewed and owned land had subdivided their land and sold or leased it out. Moreover, $76.5 \%$ of those interviewed own less than 5 acres and only 5.5\% own more than 10.1 acres (Table 4 ). The study established that when Kimana group ranch members subdivided their land after the failure of the group ranch model, the mean size of the individual plots was $1.2 \mathrm{~km}^{2}(0.6-$ $4.6 \mathrm{~km}^{2}$ ).

The selling of land is verifiable by the fact that $80 \%$ of those interviewed were non-Maasai who had emigrated from other areas. Moreover, $69 \%$ of the total respondents who owned land in the areas indicated that they acquired it through buying and $24.5 \%$ through inheritance and $6.5 \%$ (all migrants) had rented the land they were using.

\subsection{Effects of Land Use Change on Wild Ungulates in Kimana} Wetland Ecosystem. In the views of $89 \%$ of those interviewed, changes in land use patterns in the study had significant effects on the wild ungulate populations $\left(\chi^{2}=121.68, \mathrm{DF}=\right.$ $1, P=0.000$ ). The main effects include noticeable decline in wild ungulate numbers, encroachment into wetlands and other wildlife habitats, significant increase in incidences of human-wildlife conflicts $\left(\chi^{2}=162.00\right.$, DF $=1, P=$ 0.000 ), habitat destruction, displacement of wild ungulates by livestock, land degradation, and emergence of invasive plant species.

5.7. Trends in Abundance of Wild Ungulates in Kimana Wetland Ecosystem. Wild animal counts conducted in the study area from 1979 to 2010 by various institutions on four species of wild ungulates have showed a decline in their numbers. As per the 1979 animal count, wildebeest which had a population estimate of approximately 6,700 individuals was the most numerous wild ungulate, followed by common zebra $(5,600)$, Grant's gazelle $(5,495)$, and impala (4820). In 2010,

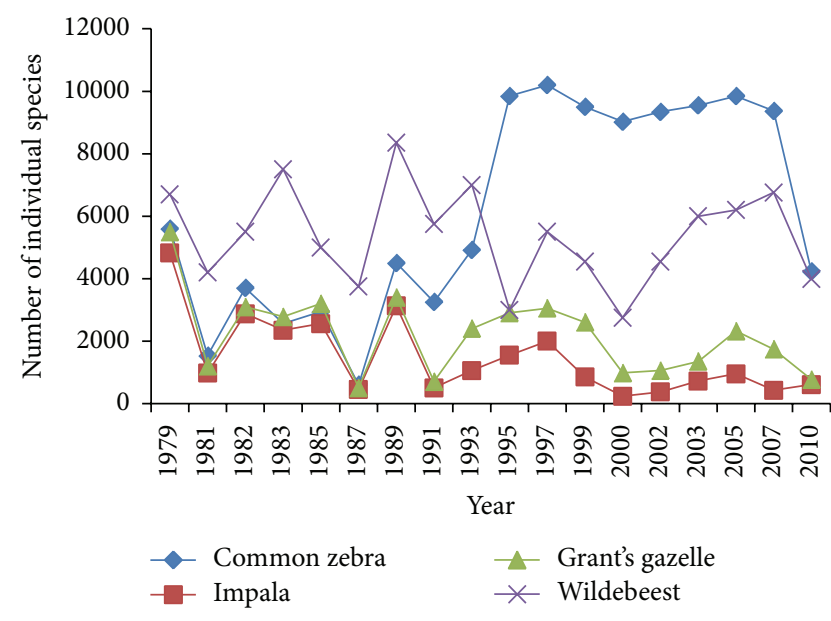

Figure 4: Population estimates for zebra, impala, G. gazelle, and wildebeest in KWE (1979 to 2010). Source: DRSRS and KWS.

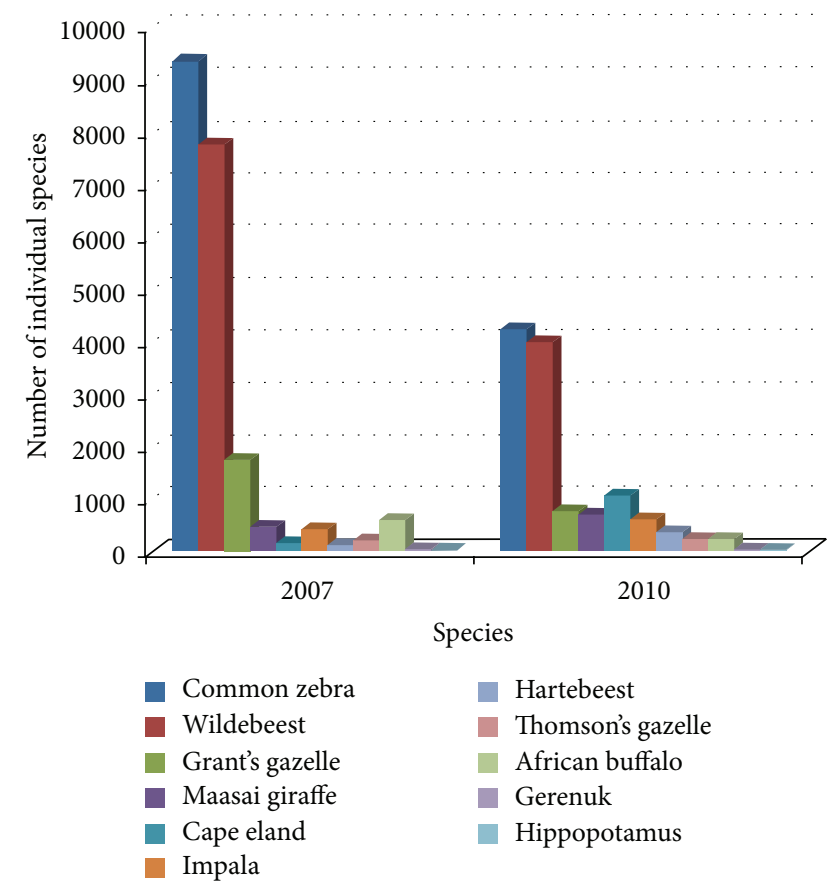

FIgURE 5: Wild ungulate population estimates for 2007 and 2010 in KWE. Source: DRSRS and KWS.

common zebra was the most numerous with a population estimate of 4,232 followed by wildebeest $(3,990)$, Grant's gazelle (769), and impala (607) (Figure 4).

A comparison of 2007 and 2010 count for the same species in the same area indicated a decline in numbers for common zebra, Grant's gazelle, and wildebeest species and an increase for impala. For example, the population of common zebra from 2007 to 2010 dropped by $54.8 \%$, Grant's gazelle by $55.8 \%$, and wildebeest by $48.6 \%$, while impala increased by $42 \%$ (Figure 5).

The results from aerial counts carried out in Kimana wetland ecosystem from 2000 to 2010 indicated a decline in the number of African buffaloes from 367 in 2000 to 200 in 
TABLE 5: Characteristics of interviewee opinions in regard to land use changes and their effects on wild ungulates.

\begin{tabular}{|c|c|c|c|}
\hline Information sought & Responses from respondents & $\begin{array}{l}\text { Number of respondents } \\
\quad(n=200)\end{array}$ & $\begin{array}{l}\text { Chi square goodness of fit; } \\
\text { df; } P \text { value }\end{array}$ \\
\hline \multirow{2}{*}{ Gender } & Male & 147 & \multirow{2}{*}{$r=44.180, \mathrm{df}=1, P=0.000$} \\
\hline & Female & 53 & \\
\hline \multirow{3}{*}{ Age } & $18-35$ & 77 & \multirow{3}{*}{$r=7.090, \mathrm{df}=2, P=0.029$} \\
\hline & $36-50$ & 74 & \\
\hline & Above 51 & 49 & \\
\hline \multirow{4}{*}{ Level of education } & None & 45 & \multirow{4}{*}{$r=26.520, \mathrm{df}=3, P=0.000$} \\
\hline & Primary & 74 & \\
\hline & Secondary & 57 & \\
\hline & Tertiary & 24 & \\
\hline \multirow{7}{*}{ Source of livelihood } & Crop farming & 78 & \multirow{7}{*}{$r=123.400, \mathrm{df}=6, P=0.000$} \\
\hline & Livestock & 35 & \\
\hline & Rural self-employed & 15 & \\
\hline & Urban self-employed & 15 & \\
\hline & Wage employment & 6 & \\
\hline & Crop farming and livestock & 34 & \\
\hline & Livestock and wildlife & 17 & \\
\hline \multirow{5}{*}{ Length of stay } & $<5 \mathrm{yrs}$ & 33 & \multirow{5}{*}{$r=60.700, \mathrm{df}=4, P=0.000$} \\
\hline & $5.1-10 \mathrm{yrs}$ & 36 & \\
\hline & $10.1-15 \mathrm{yrs}$ & 83 & \\
\hline & $15.1-20 \mathrm{yrs}$ & 23 & \\
\hline & Above $20.1 \mathrm{yrs}$ & 25 & \\
\hline \multirow{5}{*}{ Individual size of land } & $<2.5$ Acres & 80 & \multirow{5}{*}{$r=112.650, \mathrm{df}=4, P=0.000$} \\
\hline & 2.5-5 Acres & 73 & \\
\hline & 5.1-7.5 Acres & 20 & \\
\hline & 7.6-10 Acres & 16 & \\
\hline & Above 10.1 Acres & 11 & \\
\hline \multirow{5}{*}{ Current land use } & Crop farming & 88 & \multirow{5}{*}{$r=76.450, \mathrm{df}=4, P=0.000$} \\
\hline & Livestock & 35 & \\
\hline & Wildlife & 18 & \\
\hline & Commercial & 33 & \\
\hline & Crop farming and livestock & 26 & \\
\hline \multirow{2}{*}{$\begin{array}{l}\text { Has the land use been changing over } \\
\text { the years? }\end{array}$} & Yes & 180 & \multirow{2}{*}{$r=128.000, \mathrm{df}=1, P=0.000$} \\
\hline & No & 20 & \\
\hline \multirow{2}{*}{ Has LUC affected wild ungulates? } & Yes & 178 & \multirow{2}{*}{$r=115.520, \mathrm{df}=1, P=0.000$} \\
\hline & No & 22 & \\
\hline \multirow{5}{*}{$\begin{array}{l}\text { Distance of the individual homestead } \\
\text { from protected areas }\end{array}$} & $0-5 \mathrm{~km}$ & 89 & \multirow{5}{*}{$r=85.050, \mathrm{df}=4, P=0.000$} \\
\hline & $5.1-10 \mathrm{~km}$ & 19 & \\
\hline & $10.1-15 \mathrm{~km}$ & 20 & \\
\hline & $15.1-20 \mathrm{~km}$ & 44 & \\
\hline & Over 20.1 & 28 & \\
\hline \multirow{8}{*}{ Causes of land use change } & Agricultural expansion & 63 & \multirow{8}{*}{$r=129.760, \mathrm{df}=7, P=0.000$} \\
\hline & Economic forces & 26 & \\
\hline & Politics & 21 & \\
\hline & Changing land tenure policy & 21 & \\
\hline & Human population increase & 51 & \\
\hline & Drought & 8 & \\
\hline & Poverty & 6 & \\
\hline & Education level & 4 & \\
\hline
\end{tabular}


TABLe 5: Continued.

\begin{tabular}{|c|c|c|c|}
\hline Information sought & Responses from respondents & $\begin{array}{l}\text { Number of respondents } \\
\quad(n=200)\end{array}$ & $\begin{array}{l}\text { Chi square goodness of fit; } \\
\text { df; } P \text { value }\end{array}$ \\
\hline \multirow{2}{*}{ Is there HWC? } & Yes & 190 & \multirow{2}{*}{$r=162.000, \mathrm{df}=1, P=0.000$} \\
\hline & No & 10 & \\
\hline \multirow{6}{*}{ Forms of HWC } & Crop destruction & 88 & \multirow{6}{*}{$r=141.820, \mathrm{df}=5, P=0.000$} \\
\hline & Livestock predation & 50 & \\
\hline & Human injuries & 17 & \\
\hline & Death of human being & 26 & \\
\hline & Road kills & 11 & \\
\hline & Competition for food & 8 & \\
\hline \multirow{4}{*}{$\begin{array}{l}\text { Period of the year when the conflicts } \\
\text { are severe }\end{array}$} & January-March & 41 & \multirow{4}{*}{$r=59.320, \mathrm{df}=3, P=0.000$} \\
\hline & April-June & 25 & \\
\hline & July-September & 96 & \\
\hline & October-December & 38 & \\
\hline
\end{tabular}

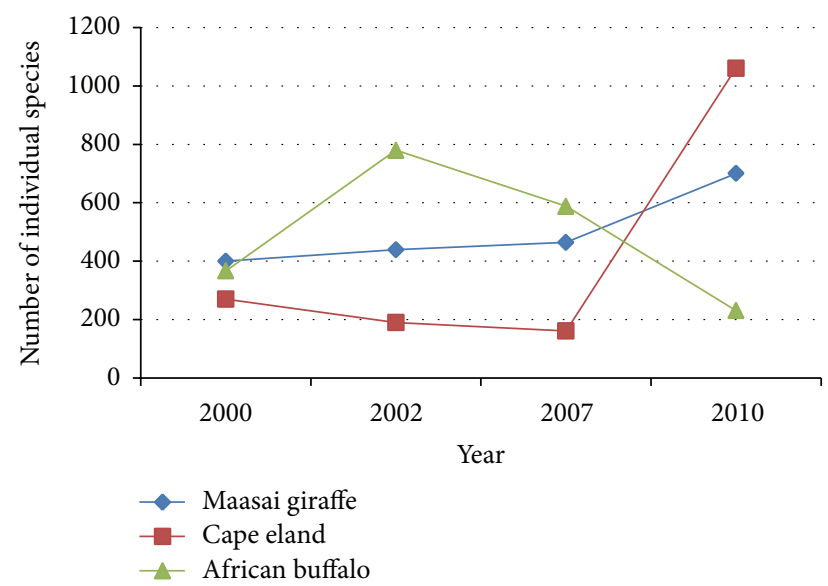

FIGURE 6: Population estimates for giraffe, eland, and buffalo in KWE (2000 to 2010). Source: DRSRS and KWS.

2010 (46.8\% decrease) and that of the Maasai giraffe remained relatively stable with a slight increase, while that of the Cape eland rose from less than 200 individuals in 2007 to more than 1000 individuals in 2010 (Figure 6). In 2000, most of the buffaloes were in ANP (80.9\%) and Kimana Sanctuary $(10.9 \%)$ and the rest (8.2\%) were in Kuku group ranch. All the buffaloes counted in 2007 were within the protected area.

5.8. Livestock Population Trend in Kimana Wetland Ecosystem. Indigenous cattle (Zebu), goats, sheep, and donkeys are the main livestock types kept in the study area. In the recent past, farmers have started keeping dairy cattle (mainly Friesian) under intensive zero grazing system. Livestock population figures over the past three decades show that the numbers of cattle, goats, and sheep are on the increase in KWE [25]. Aerial counts for livestock in KWE from 2000 to 2010 indicate an upward trend. Goats and sheep appeared to have increased in the last ten years with a total population of 104,520 in 2010 compared to 49,230 in 2000 .
5.9. Tourism Activities. KWE is among the most popular tourist destinations with Amboseli National Park being one of the premium parks in Kenya. Development of tourism facilities within KWE has been rapid in response to the increasing number of tourists. In 1980, for example, the study found that there were only five hotels and lodges but at present, there are over 25 hotels, lodges, and campsites with a capacity of over 1,700 beds. In an attempt to have tourists view wildlife at a close range, roads and nature trails have been constructed in ecologically fragile areas that serve as breeding and calving grounds for most wild ungulate species. These infrastructures have also disrupted wild ungulate migration patterns and increased habitat fragmentation.

5.10. Human-Wildlife Conflict (HWC). HWC incidences, which were rare in the 1980s, have been frequent as testified by $95 \%$ of the respondents. Of these, $88.5 \%$ have been victims of the conflicts. The most severe forms of HWC, in their views, were crop and property damage by wild ungulates (44\%), livestock predation by carnivores (25\%), death and injury of human being ( $13 \%$ and $8 \%$, resp.), road kills $(6 \%)$, and competition for resources between human, livestock, and wild ungulates (Figure 7).

\section{Discussion and Conclusions}

KWE is critical wildlife dispersal, breeding, and dry season grazing area for Amboseli and Tsavo ecosystems [17]. Poor land use zoning and land use controls have led to emergence of uncoordinated and conflicting land use types in KWE [26]. The decline in land under wetland, forestland, grassland, and woodland that are wildlife habitats signifies that wildlife conservation is not an important source of livelihood for the locals of KWE. It is, therefore, not possible to convince the local people to conserve the wildlife habitat because of its advantage in the long-term. Of notable concern is lack of direct benefits from the wildlife based-tourism industry. In contrast, the local people do receive direct benefits from horticultural farming and selling or renting out their land. 


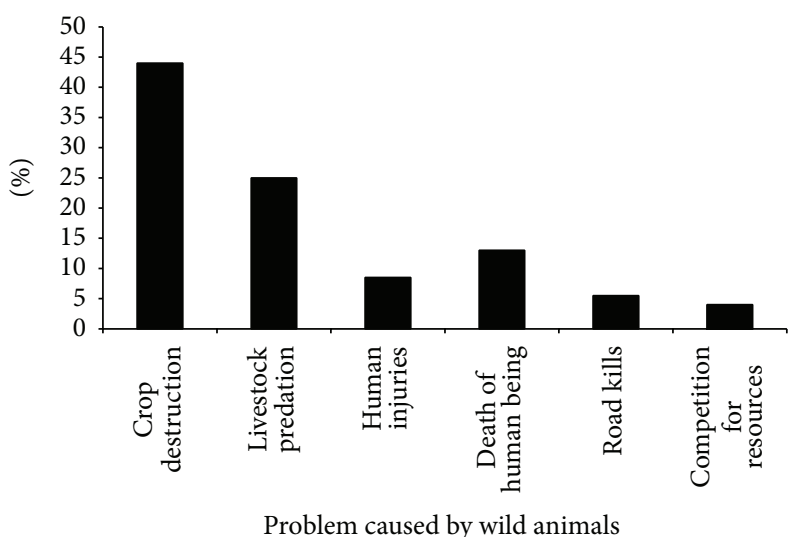

FIGURE 7: Problems caused by wild animals in KWE. Source: author, 2013.

Therefore, it is no surprise that they have increasingly cleared their land for irrigated farming, human settlement, and infrastructure development in recent past at the expense of wildlife conservation.

Traditionally, land in KWE was communally owned. This system made it possible to practice nomadic pastoralism, which ensured sustainable livestock production and conservation of wildlife. However, because of changes in government policy such as repealing of the "Land Group Representatives and Land Adjudication Act" of 1968, communally owned land has been subdivided into individual plots. This has resulted into expansion of farmland by $526.21 \%$, settlement and urban areas by $681.57 \%$, and other lands by $195.43 \%$ between 1980 and 2013 . In addition, the area under wetland has decreased by $68.93 \%$, forestland by $47.56 \%$, grassland by $8.1 \%$, and woodland by $5.35 \%$ during the same period.

The shift from wildlife conservation and pastoralism to irrigated agriculture is not entirely new among pastoral community. However, in KWE, it has taken a more commercial nature rather than subsistence farming leading to expansion of farmlands through clearing of wetlands, forests, grassland, and woodland. This has led to loss of key wetlands and other wildlife habitats, which used to serve as grazing area for livestock and wild ungulates. Land that is adjacent to wetland that used to serve as a wildlife dispersal area has now become individual property. Wild ungulates are no longer able to access the areas that have been converted into farmland and human settlements. Hence, large number of wild ungulates concentrate in areas without (or with little) farms and human settlement. Wild ungulates have completely avoided urban areas and build areas such as schools, dispensaries, and market places.

The subdivision of group ranches into individual plots has also resulted in establishment of community sanctuaries. The community sanctuaries are usually too small in area to be viable conservation units for they are not linked to each other. They are fragmented wildlife habitats. A preposition is also supported by Young and McClanahan [27], who argued that community wildlife sanctuaries represent a fragment of the entire ecosystem and violate good design approaches based on principles of island biogeography. When these community wildlife sanctuaries are established in isolation from other protected areas, without linking them by wildlife corridors, they result in isolation of protected areas. The isolation of protected areas is likely to result in inbreeding of wild animals, thus lowering their survival ability.

Overstocking of livestock by pastoralist has led to overgrazing in the study area particularly in areas outside protected areas. The impacts of overgrazing as observed during the field visit include land degradation, soil erosion, and emergence of invasive plant species such as Lantana camara and Solanum incanum. The latter is a drought resistant nonpalatable herbaceous plant that does not have any natural enemy and thrives well in disturbed ecosystem. The study found that it was thriving well in areas that had been overgrazed, on edges of human settlement and along built areas. It dominates the herbaceous layer thus hindering the growth of grass species and hinders free movement of livestock and wild ungulates.

The fate of Kenya's wildlife, therefore, depends on the future of the protected areas and the surrounding wildlife dispersal areas. Changing land use patterns in KWE have led to loss of key dry season grazing ground for wild ungulates and decline in wild ungulate numbers in the last three decades. To alleviate the changing land use patterns and counter their impacts on wild ungulates, the study recommends the following: zoning of KWE into three categories (wildlife areas, settlement area, and farming area); establishment of an effective, transparent, fair, and equitable wildlife benefitsharing scheme; establishment of an effective and transparent management system for managing community conservancies; rehabilitation of Kimana community wildlife sanctuary; and farmers to embrace technology in their irrigated farming. The future of wild ungulates in KWE is doomed unless appropriate measures are put in place to reverse the observed detrimental trends. It is extremely urgent, therefore, that all the proposed measures by this study be taken into consideration in order to strike a balance between wildlife conservation and economic development if the observed detrimental trends are to be reversed.

Areas for Further Research. (i) Kimana Community Wildlife Sanctuary was the first community sanctuary to be established in Kenya in 1996 but, due to poor management systems, it has collapsed. Therefore, more studies need to be carried out to determine the effectiveness of community involvement in the management of wildlife. (ii) There have been many wildlife conservation and management policies which have been put in place to conserve and manage wildlife. It is, therefore, necessary to analyze wildlife conservation and management policies in Kenya with a view of determining their effectiveness.

\section{Conflict of Interests}

The authors declare that there is no conflict of interests regarding the publication of this paper. 


\section{Acknowledgments}

The authors acknowledge the Kenya Wildlife Service which made it possible for this study to be carried out and also Mr. Dennis Macharia from RCMRD, for availing the ARCGIS and EDRAS software used to perform image and data analysis.

\section{References}

[1] T. Flannery, The Eternal Frontier: An Ecological History of North America and Its Peoples, Atlantic Monthly Press, New York, NY, USA, 2001.

[2] H. H. T. Prins, "The pastoral road to extinction: competition between wildlife and traditional pastoralism in East Africa," Environmental Conservation, vol. 19, no. 2, pp. 117-123, 1992.

[3] C. Van Der Waal and B. Dekker, "Game ranching in the Northern Province of South Africa," South African Journal of Wildlife Research, vol. 30, no. 4, pp. 151-156, 2000.

[4] Z. A. Ogutu, "The impact of ecotourism on livelihood and natural resource management in Eselenkei, Amboseli Ecosystem, Kenya," Land Degradation and Development, vol. 13, no. 3, pp. 251-256, 2002.

[5] Government of Kenya, The National Wildlife Conservation and Management Policy, 2012, Ministry of Forestry and Wildlife, Government Printer, 2011.

[6] D. T. Bolger, W. D. Newmark, T. A. Morrison, and D. F. Doak, "The need for integrative approaches to understand and conserve migratory ungulates," Ecology Letters, vol. 11, no. 1, pp. 63-77, 2008.

[7] D. Western, S. Russell, and I. Cuthil, "The status of wildlife in protected areas compared to non-protected areas of Kenya," PLoS ONE, vol. 4, no. 7, Article ID e6140, 2009.

[8] D. Western and D. L. Manzolillo-Nightingale, "Environmental change and the vulnerability of pastoralists to drought: a case study of the Maasai in Amboseli, Kenya," in Africa Environment Outlook Case Studies: Human Vulnerability to Environmental Change, pp. 35-50, UNEP, Nairobi, Kenya, 2004.

[9] J. M. Grunblatt, M. Said, and P. Wargute, National Rangelands Report. Summary of Population Estimates of Wildlife and Livestock (1977-1994), Department of Resource Surveys and Remote Sensing, Ministry of Planning and National Development, Nairobi, Kenya, 1996.

[10] IUCN, IUCN Red List of Threatened Species, IUCN, Gland, Switzerland, 2008, http://www.iucnredlist.org/.

[11] M. Loibooki, H. Hofer, K. L. I. Campbell, and M. L. East, "Bushmeat hunting by communities adjacent to the Serengeti National Park, Tanzania: the importance of livestock ownership and alternative sources of protein and income," Environmental Conservation, vol. 29, no. 3, pp. 391-398, 2002.

[12] M. Norton-Griffiths, M. Y. Said, S. Serneels et al., "Land use economics in the mara area of the serengeti ecosystem," in Serengeti III: Human Wildlife Interactions, C. Packer and A. R. E. Sinclair, Eds., pp. 379-416, University of Chicago Press, Chicago, Ill, USA, 2009.

[13] O. E. Sala, F. S. Chapin, J. J. Armesto et al., "Global biodiversity scenarios for the year 2100," Science, vol. 287, no. 5459, pp. 17701774, 2000.

[14] E. F. Lambin, B. L. Turner, H. J. Geist et al., "The causes of landuse and land-cover change: moving beyond the myths," Global Environmental Change, vol. 11, no. 4, pp. 261-269, 2001.
[15] J. M. Maitima, M. M. Simon, R. S. Robin et al., "The linkages between land use change, land degradation and biodiversity across East Africa," African Journal of Environmental Science and Technology, vol. 3, no. 10, pp. 310-325, 2009.

[16] I. J. Gordon, "What is the future for wild, large herbivores in human-modified agricultural landscapes," Wildlife Biology, vol. 15, no. 1, pp. 1-9, 2009.

[17] M. M. Okello, E. Buthmann, B. Mapinu, and H. C. Kahi, "Community opinions on wildlife, resource use and livelihood competition in Kimana group ranch near Amboseli, Kenya," Open Conservation Biology Journal, vol. 5, no. 1, pp. 1-12, 2011.

[18] W. D. Newmark, "The role and design of wildlife corridors with examples from Tanzania," Ambio, vol. 22, no. 8, pp. 500-504, 1993.

[19] D. J. Campbell, H. Gichohi, A. Mwangi, and L. Chege, "Land use conflict in Kajiado District, Kenya," Land Use Policy, vol. 17, no. 4, pp. 337-348, 2000.

[20] I. Sindiga, "Wildlife based tourism in Kenya: land use conflicts and government compensation polices over protected areas," Journal Tourism Study, vol. 6, no. 2, pp. 45-55, 1995.

[21] M. M. Okello, "Land use changes and human-wildlife conflict in the Amboseli Area," Human Dimension Wildlife, vol. 10, no. 1, pp. 19-28, 2005.

[22] M. M. Okello and J. W. Kiringe, "Threats to biodiversity and their implications in protected and adjacent dispersal areas of Kenya," Journal of Sustainable Tourism, vol. 12, no. 1, pp. 55-69, 2004.

[23] M. M. Okello, "Contraction of wildlife dispersal area and displacement by human activities in Kimana Group Ranch near Amboseli National Park, Kenya," Conservation Biology Journal, vol. 3, pp. 49-56, 2009.

[24] J. H. Zar, Biostatistical Analysis, Prentice-Hall, Upper Saddle River, NJ, USA, 4th edition, 1999.

[25] Government of Kenya, Loitokitok District Development Plan 2008-2012, The Government Printer, Nairobi, Kenya, 2008.

[26] KWS, Amboseli Ecosystem Management Plan 2008-2018, KWS, Nairobi, Kenya, 2009.

[27] T. P. Young and T. R. McClanahan, "Island biogeography and species extinction," in East African Ecosystems and Their Conservation, T. R. McClanahan and T. P. Young, Eds., pp. 292293, Oxford University Press, New York, NY, USA, 1996. 

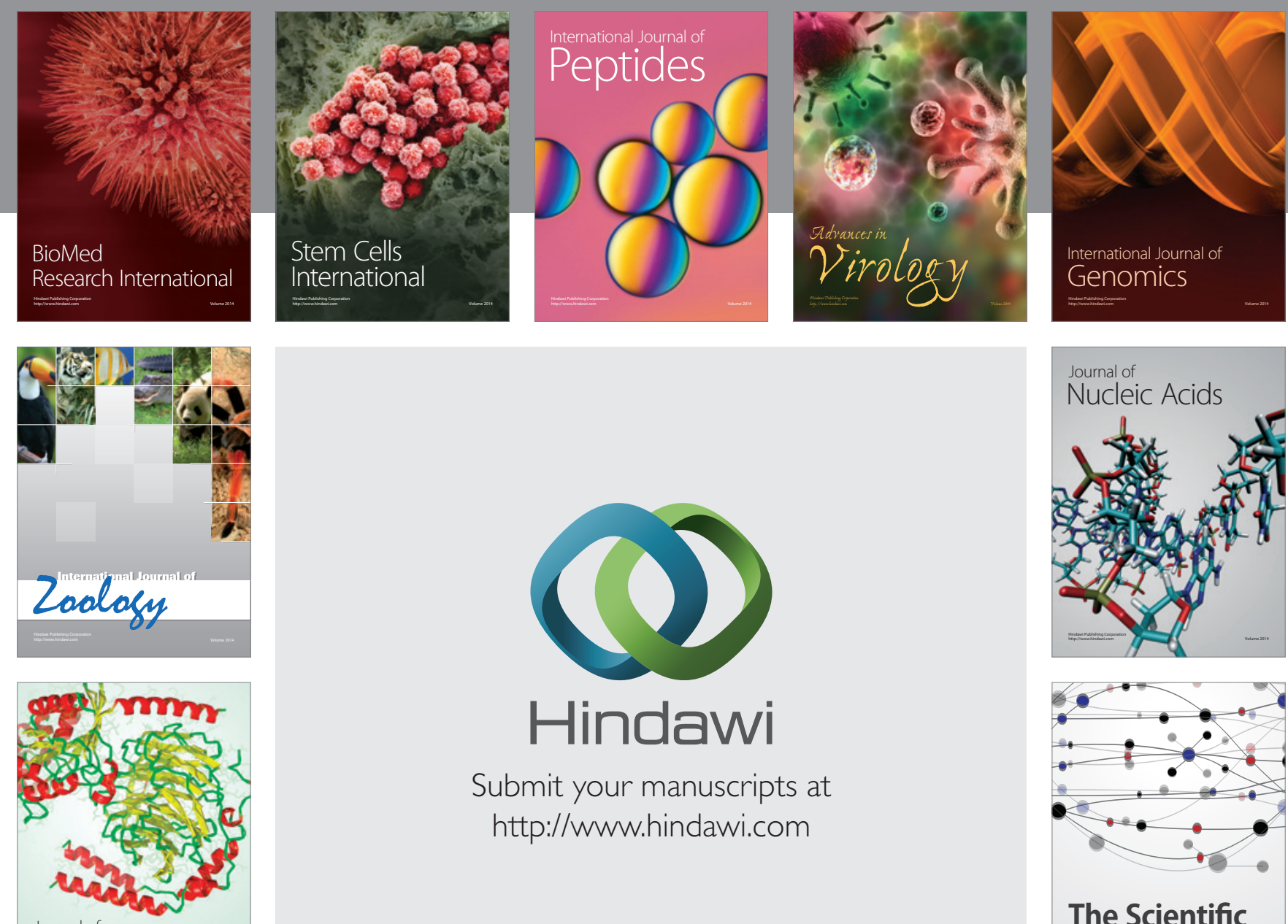

Submit your manuscripts at

http://www.hindawi.com

Journal of
Signal Transduction
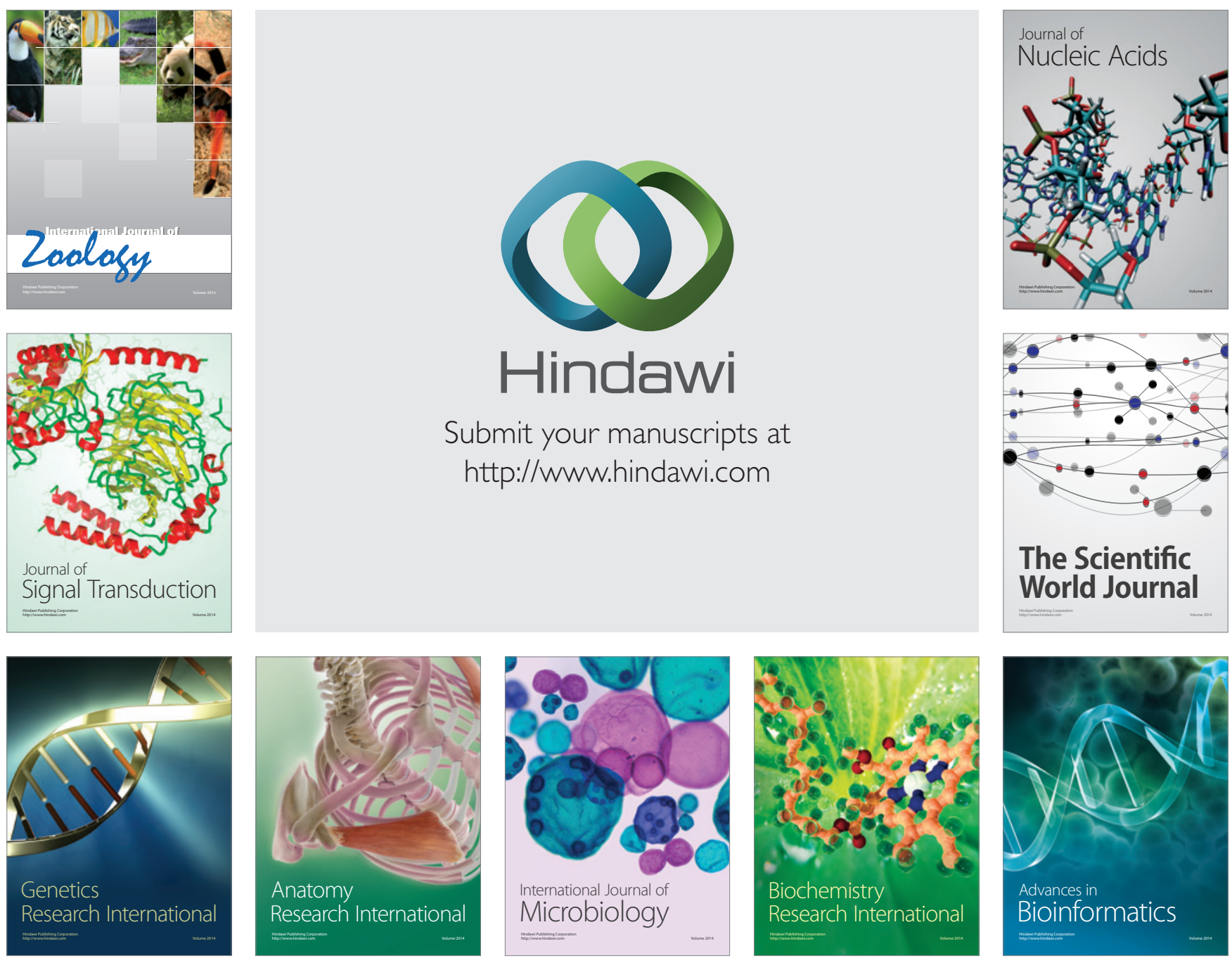

The Scientific World Journal
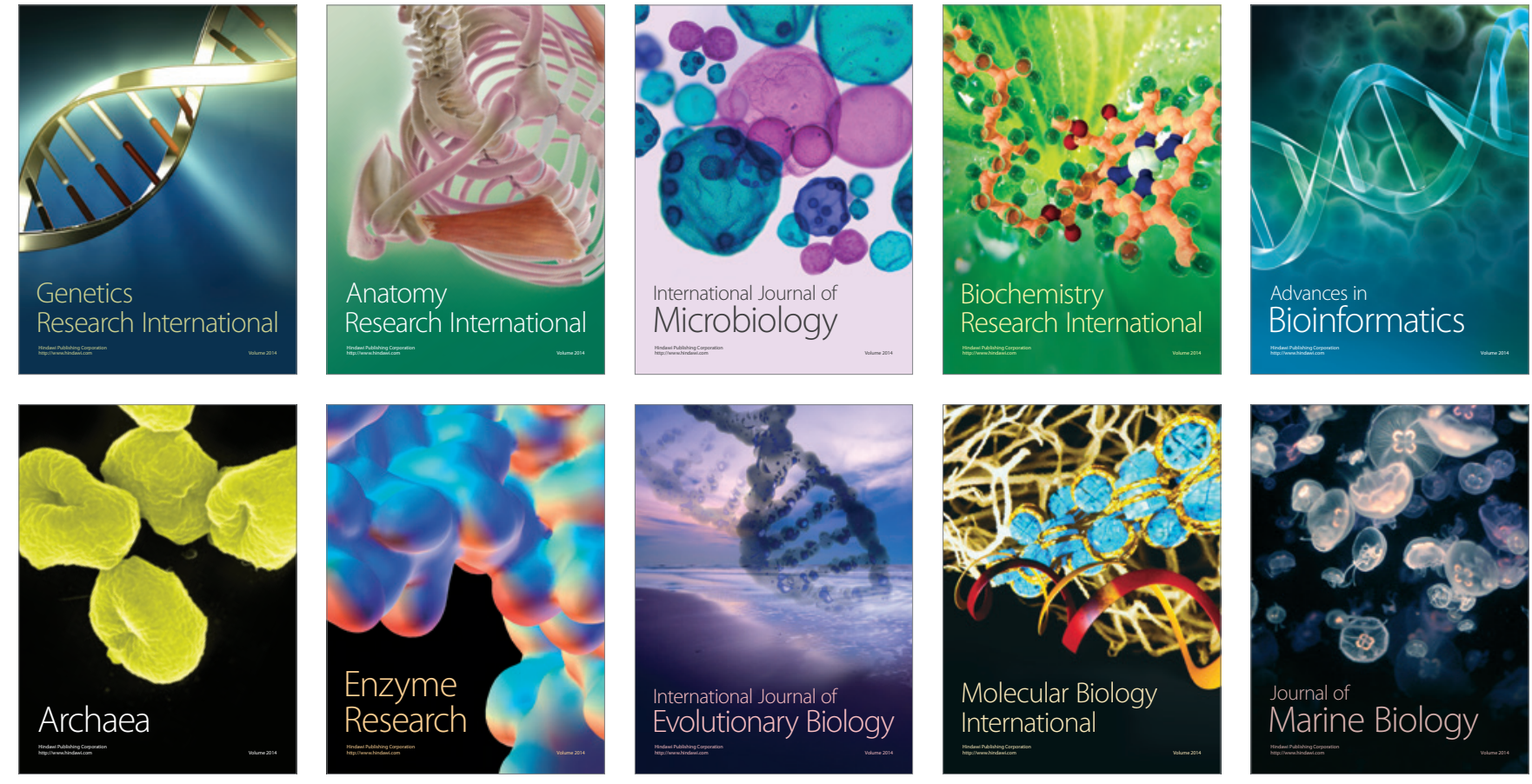